СТАТИСТИКА, ОБЛІК, АНАЛІЗ ТА АУДИТ

УДК 658.511

JEL Classification: C41
DOI: 10.37332/2309-1533.2019.7-8.19

Хорунжак Н.М., д-р екон. наук, професор кафедри обліку та оподаткування, Портоварас Т.P., канд. екон. наук, викладач кафедри менеджменту, публічного управління та персоналу, Тернопільський національний економічний університет

АНАЛІЗ ОПЕРАЦІЙНИХ ВИТРАТ: ДЖЕРЕЛА ТА МЕТОДИ

\author{
Khorunzhak N.M., \\ dr.sc.(econ.), professor at the department \\ of accounting and taxation, \\ Ternopil National Economic University, \\ Portovaras T.R., \\ cand.sc.(econ.), lecturer at the department of \\ management, public administration and personnel, \\ Ternopil National Economic University
}

\title{
OPERATING COST ANALYSIS: SOURCES AND METHODS
}

Постановка проблеми. Сучасні економічні тенденції потребують нових підходів до методів аналізу операційних витрат підприємств, що зумовлено посиленням ринкової конкуренції та прагненням підприємств отримувати максимальні доходи, а також необхідністю ефективного формування витрат. Виконання такого завдання можуть забезпечити методи стратегічного управління, які відстежують зміни в економічному середовищі й дають змогу здійснювати прогнозування витрат підприємств з метою розвитку підприємств в перспективі і надання соціальних гарантій працівникам. Тому застосування стратегічного підходу до операційних витрат підприємства, дослідження його критеріїв та методів оцінки обумовлюють актуальність даної статті.

Аналіз останніх досліджень і публікацій. Вагомий внесок у теорію дослідження стратегічних підходів та вибору найбільш ефективних методів його здійснення зробили такі відомі зарубіжні й українські науковці та фахівці-практики, як: Абрамова О. В. [1], Бланк І. А. [5], Друрі К. [7], Котляров С. А. [10], Нападовська Л. В. [11], Фандель Г. [14], Фокін О. К. [15], Череп А. В. [16] та інші.

В основному автори висвітлюють загальні засади аналізу, його методи, а також результати та роль в прийнятті управлінських рішень. Багато уваги приділяється дослідженню теоретичних питань проведення аналізу операційних витрат.

Так, Дьордяй В. П. та Макарович В.К.[8] стверджують, що аналіз ефективного управління операційними витратами потребує якісної класифікації та порядку визначення витрат. Автори узагальнюють власне дослідження саме в такій площині.

Також науковці досліджують умови визнання, оцінки та складу витрат операційної діяльності підприємства, теоретичні аспекти управління ними й акцентують увагу на тому, що витрати є однією 3 найголовніших економічних категорій, яка характеризує ефективність використання ресурсів і визначає рентабельність діяльності. Окрім цього, пропагується думка, що підприємства для повної економічної самостійності і відповідальності за результати своєї діяльності мають створити умови ефективного управління операційними витратами виробництва. 3 цією метою слід приділяти увагу їх плануванню, обліку, аналізу й контролю. Необхідною умовою при цьому є обґрунтована класифікація витрат, тобто їх розподілення на певні класи з урахуванням загальних критеріїв та об'єктивних зв'язків між ними [12]. 
Чичуліна К. В. та Чапча І. О. на конкретному прикладі доводять важливість стратегічного управління витратами й стверджують, що воно є одним із важливих шляхів забезпечення розвитку підприємства та конкурентоспроможності його продукції на ринку. При цьому автори приділяють увагу проблемі мінімізації витрат в загальній сумі чистого доходу на засадах ефективного використання виробничих ресурсів та структурних змінах якісного характеру управління ними [17].

Разом із тим, потребує подальшого дослідження систематизація методів аналізу операційних витрат для оцінки діяльності підприємств 3 подальшим удосконаленням напрямків їх розвитку. Дослідження операційних витрат як у вітчизняній, так і в зарубіжній практиці показало, що недостатню увагу приділено методам його здійснення. Аналіз у даній площині проводиться здебільшого фрагментарно, тобто використовуються, як правило, застарілі методики оцінки, що не дозволяє виявити усі негативні фактори впливу та попередити кризові явища на підприємствах. Необхідність даного дослідження зумовлена тим, що, згрупувавши методи аналізу операційних витрат відповідно до поставлених цілей, можемо швидко і ефективно оцінити ситуацію, що дозволить зміцнити позиції підприємства у конкурентному середовищі.

Постановка завдання. Для проведення якісного аналізу операційних витрат необхідний правильний вибір джерел і визначення методів аналізу операційних витрат. Саме ці два чинники мають винятковий вплив на адекватність результатів аналізу і подальші управлінські дії щодо діяльності підприємства 3 попередження і нівелюванні кризових явищ. Метою дослідження $€$ ідентифікація вимог і складу джерел аналізу, критична оцінка їх інформаційності, а також акцент на застосуванні системного підходу при здійсненні аналізу операційних витрат і відповідність його методу цим критеріям.

Виклад основного матеріалу дослідження. Дослідження аналізу операційних витрат показало, що і в українській, і в зарубіжній практиці недостатню увагу приділено методам його здійснення. У зв'язку з цим слід погодитися зі справедливістю думки О. В. Абрамової, що «неодмінною умовою збереження суб'єктами господарювання конкурентних позицій $€$ не тільки зниження собівартості реалізованої продукції, але й розробка аналітичного забезпечення стратегічного управління витратами, спрямованого на пошук резервів формування стійкої конкурентної переваги за витратами» [1, с. 1].

Попри це, варто також визнати, що сучасні підприємства в Україні недостатньо активно користуються аналітичним інструментарієм для поліпшення результативності власної діяльності. $Є$ низка причин цього явища в нашій економіці. По-перше, прагнення економити на будь-чому, що пояснюється як складним економічним становищем самих суб'єктів, так і недостатнім рівнем інформованості про можливі позитивні результати від проведення аналізу діяльності. По-друге, відсутність високопрофесійних фахівців, які б володіли методологією та способами аналізу й орієнтувалися в галузевій специфіці конкретного суб'єкта, запитах його системи управління, а також можливостях отримання необхідної результатної інформації.

Низка науковців вважають, що однією 3 головних причин нераціонального управління операційними витратами українських виробників виступає відсутність сучасного аналітичного забезпечення управління витратами, адаптованого до господарської діяльності підприємства в оперативному та стратегічному аспектах, що призводить до прийняття необґрунтованих управлінських рішень через нерозуміння механізму цільової собівартості, а отже, як наслідок, зниження прибутковості окремого підприємства $[1 ; 2 ; 3 ; 7 ; 8 ; 12 ; 13 ; 15 ; 17]$. Окрім того, однією 3 проблем проведення аналізу витрат операційної діяльності є забезпечення вдалого поєднання інформаційної бази та формулювання його завдань, позиціонування об'єктів, моделювання підходу до вибору фракторів впливу та пошуку шляхів мінімізації витрат. В цьому випадку існує потреба в розширенні інформаційної бази аналізу, розвитку його інструментарію, удосконаленні методики й техніки, особливо щодо витрат операційної діяльності. В сучасних умовах аналіз операційних витрат базується в основному на даних системи обліку. Однак досягнення адекватності оцінки як досягнень, так і перспектив виявлення резервів підвищення ефективності діяльності вимагає застосування дещо ширшого кола інформаційних даних. У зв'язку з цим джерела інформації для аналізу операційних витрат доцільно розмежувати за двома групами: внутрішні (отримані із системи обліку) та зовнішні (взяті із зовнішніх джерел, в т.ч. статистичних довідників тощо). Кожна з названих груп відіграє свою роль в процесі аналізу, однак комплексно всі джерела уможливлюють отримання більш точних, якісніших і адекватніших результатів аналізу. Внутрішніми джерелами даних для аналізу $є$ облікова документація, зовнішніми - усі можливі інформаційні ресурси зовнішнього характеру (довідники, інтернет-інформація, дані обліку й звітності інших суб'єктів господарювання, офіційна інформація 3 сайтів міністерств, відомств, контролюючих і регулюючих органів тощо). Використання даних 3 вказаних джерел забезпечує отримання результатної інформації, прийнятної для вирішення проблемних питань, пов'язаних з діяльністю суб'єкта господарювання (рис. 1). 


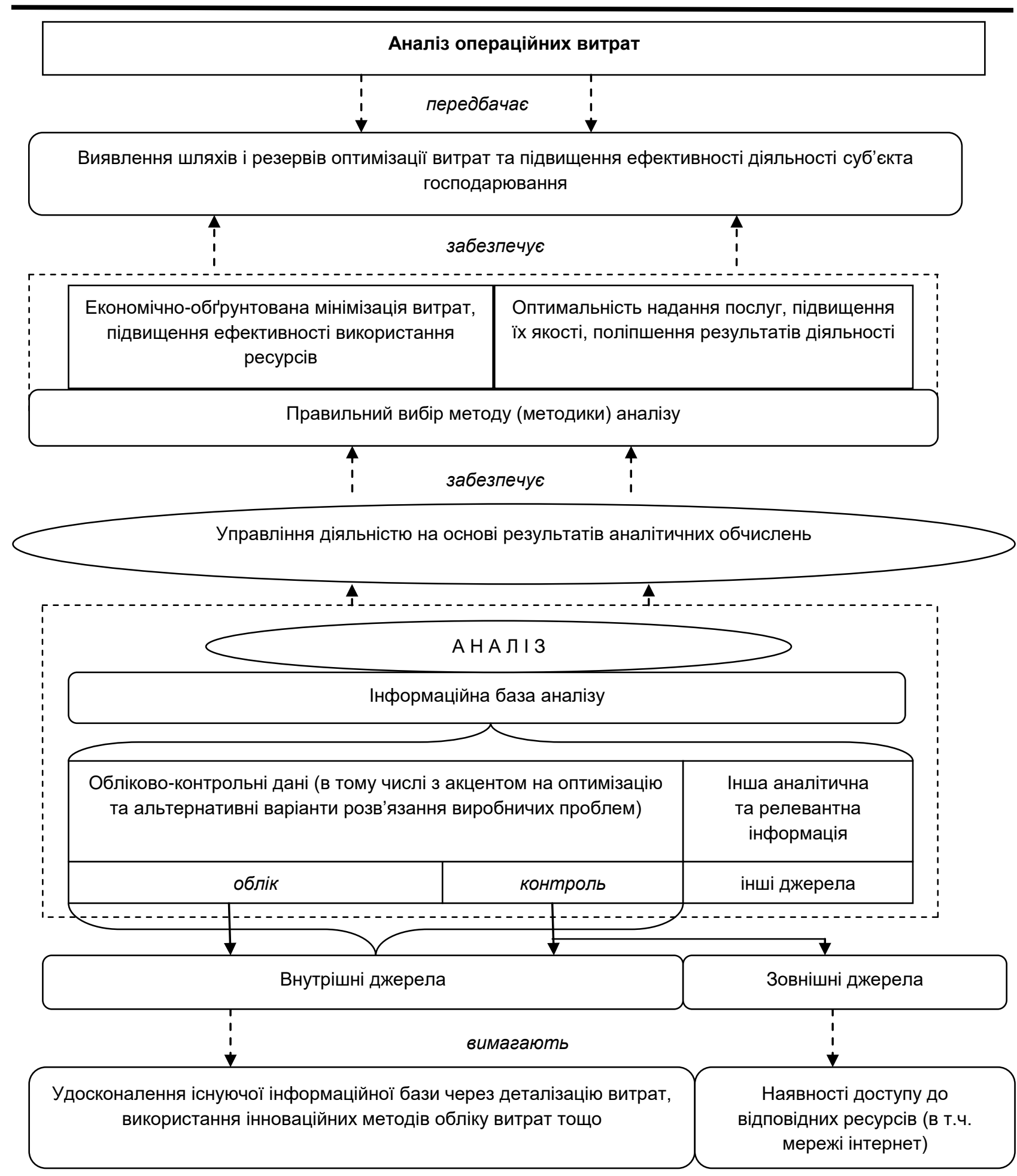

Рис. 1. Загальна схема взаємозв'язку джерел і результатів аналізу операційної діяльності Джерело: узагальнено авторами з урахуванням запропонованого підходу до класифікації джерел аналізу

До внутрішніх джерел інформації проведення аналізу операційних витрат, наприклад, для суб'єкта, що здійснює роздрібну торгівлю залізними виробами, будівельними матеріалами та санітарно-технічними виробами в спеціалізованих магазинах, монтаж водопровідних мереж, систем опалення та кондиціонування й виконує інші спеціалізовані будівельні роботи належать: «Звіти про витрати на виробництво і реалізацію продукції (робіт, послуг) підприємства (організації)», планові і звітні калькуляції собівартості продукції (послуг), облікові дані з аналітичних і синтетичних рахунків, котрі відображують витрати різних видів ресурсів (матеріальних, трудових, грошових), а також первинні документи, відомості, журнали з обліку витрат, звітність (фінансова та статистична) (рис. 2) тощо. 


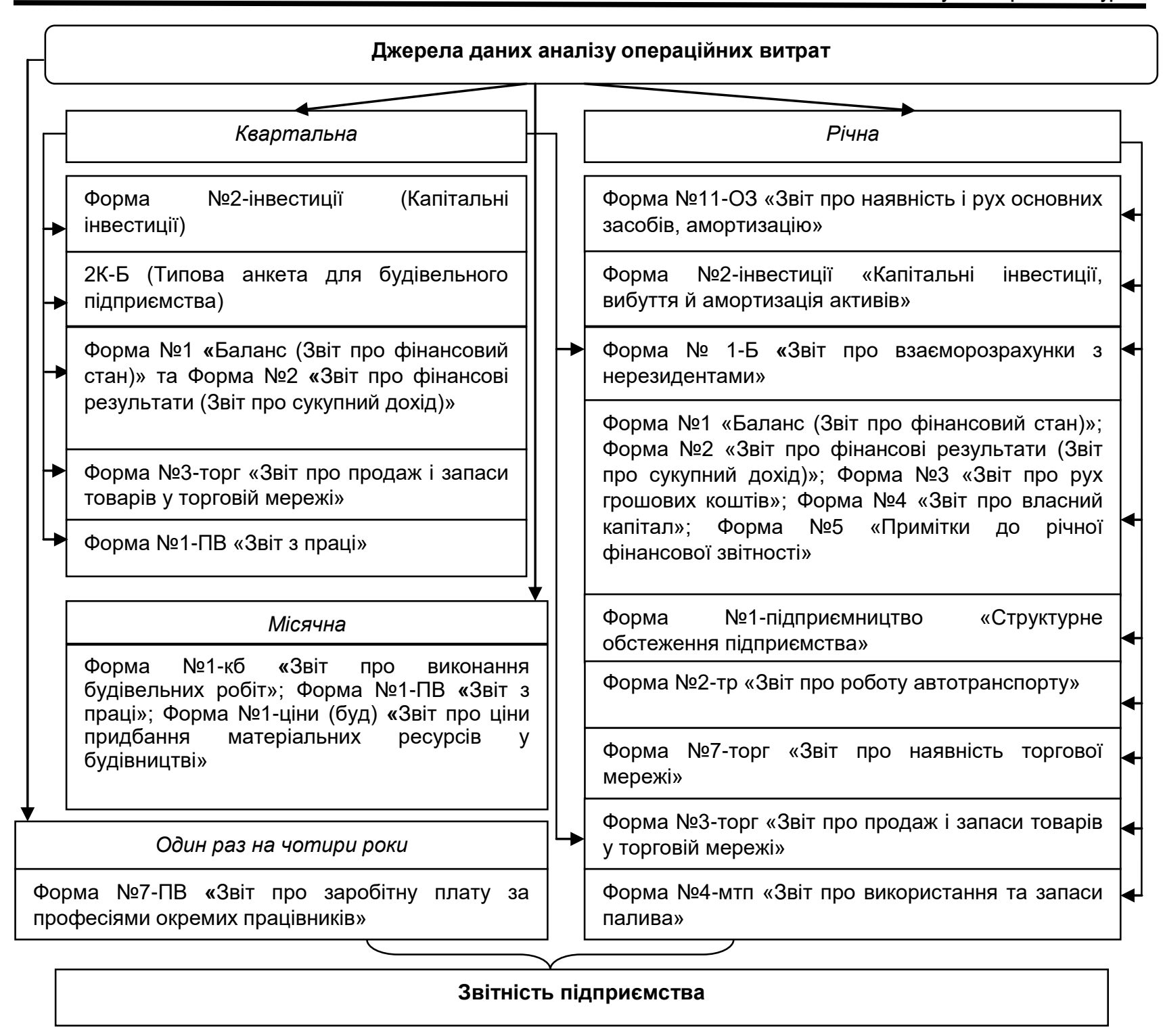

\section{Рис. 2. Звітність як джерело аналізу операційних витрат і періодичність їі формування на підприємствах}

Джерело: узагальнено авторами на основі чинної практики

Окрім звітності, для потреб аналізу може використовуватися інша інформація, котру можна віднести до внутрішніх облікових і управлінських даних: планові й звітні калькуляції собівартості продукції та послуг, що надаються; кошториси витрат на виробництво; дані синтетичного (журнали, відомості) і аналітичного обліку операційних витрат і т.і.

Також для цілей проведення аналізу операційних витрат використовуються інші джерела інформації, такі як: аналітичні розрахунки (обчислення), норми та нормативи витрачання ресурсів; дані оперативного обліку (первинні та зведені документи, регістри відпуску матеріалів, табелі обліку робочого часу та документація про нарахування заробітної плати, нормативи щодо витрат матеріалів, відхилення від норм); матеріали обстежень, перевірок, спостережень, нарад, технологічна документація, паспортні дані тощо.

До переліку зовнішніх джерел інформації слід віднести звітність суб'єктів з аналогічними видами діяльності, інформацію про собівартість їхніх послуг, дані про мережу суб'єктів аналогічного профрілю, дослідження стану ринку послуг тощо.

Використання такої інформації в комплексі забезпечує отримання за посередництва інструментів аналізу неупереджених даних, які можуть бути ефективно використані для цілей оптимізації витрат і підвищення результативності діяльності підприємств.

Така можливість пов'язана з тим, що кожне підприємство є складною системою взаємозв'язаних підрозділів і ланок, які виконують різні функції в процесі виробництва продукції. Економічний бік діяльності підприємства відображає система показників, які дають економічну оцінку процесам та результатам цієї діяльності [13, с. 68]. 
Відповідно з цим, господарська (виробнича) діяльність, як і інші явища суспільного життя, в умовах ринку та конкуренції, як ніколи, вимагає систематичного вивчення та дослідження 3 ціллю досягнення ефективного управління нею. Одним із найбільш дієвих інструментів цього процесу $є$ аналіз. Проте, як свідчить практика та дослідження літературних джерел з питань аналізу, сьогодні він повинен тісно пов'язуватися з системним підходом. Останній своєю чергою передбачає комплексне вивчення об'єкта управління (у нашому випадку операційних витрат) з урахуванням різних аспектів, в тому числі зовнішніх впливів.

Розгляд об'єктів за умови використання системного підходу передбачає, що врахування комплексу взаємозв'язаних елементів, яким притаманні як загальні характеристики (властивості), об'єднані для досягнення певної мети, так і специфічні. В спеціальній економічній літературі для ідентифікації системи рекомендовано користуватися 5 принципами: єдність мети; взаємопов'язаність структурних елементів; обмежувальне середовище; забезпечуючі ресурси; наявність керуючої системи.

Особливості системного підходу до аналізу витрат операційної діяльності свідчать, що він може забезпечити обґрунтування й підготовку управлінських рішень щодо різних питань здійснення діяльності підприємства. Саме тому аналіз слід вважати надійним інструментом вирішення проблем економіко-оптимізаційного характеру. Отож належна його організація дозволить уникати низки ризиків і формувати органічний господарський механізм, здатний задовольняти потреби споживачів у задоволенні послуг (в нашому випадку, пов'язаних зі встановленням й обслуговуванням тепло обладнання та ін.).

В цьому випадку слід визнати пріоритетність врахування результатів аналізу для потреб управління та підготовки проектів управлінських рішень.

3 огляду на те, що господарювання в сучасних умовах здійснюється в умовах повної самостійності суб'єктів у ряді питань (виробництва й реалізації продукції (послуг), планування та організації технологічних процесів, вирішенні питань щодо обсягів виробництва, структури продукції та послуг, виборі контрагентів і напрямів та шляхів реалізації тощо), правильно проведений аналіз дозволяє уникнути диспропорцій і втрат. Окрім цього, він дозволяє правильно обрати стратегію виробництва та відповідні обсяги надання послуг, що забезпечує необхідний обсяг реалізації та достойні фінансові результати.

Оцінка підходів і системи управління підприємств засвідчує, що аналіз займає важливе місце та використовується достатньо активно. Він служить основою економічного обґрунтування управлінських рішень і контролю за їх виконанням.

Проте в сучасних умовах проходять трансформації підходів до проведення аналізу, які відбуваються під впливом розвитку суспільних відносин. До таких особливостей сучасних змін економічного аналізу, порівняно 3 традиційними його фоормами, слід віднести активізацію використання принципу управління за відхиленнями, управління ризиками, застосування систем автоматичного аналізу тощо. Усе це дозволяє керівництву управляти й впливати на процеси та операції, які безпосередньо стосуються виробництва.

Науковці й практики $[14 ; 15 ; 17]$ констатують фракт підвищення оперативності аналізу, що виявляється в мінімізації періоду, за який він проводиться, відхід від обов'язкової точності його результатів, тобто перенесення центру уваги від аналізу звітності до аналізу ситуацій, цільового аналізу резервів. Незаперечним фактом сучасного функціонування вітчизняних суб'єктів господарювання $€$ також використання додаткової зовнішньої інформації. Іншою рисою сучасності $\epsilon$ також формування аналітичних груп за участі економістів і технологів, логістів (маркетологів) та юристів (залежно від сутності існуючої проблеми) для проведення економічного аналізу й використання вибіркових даних. Ще одним напрямом використання аналізу є процес проведення ревізій, аудиту, маркетингових досліджень, а також управлінського обліку. В цьому контексті слід наголосити на потребі в застосуванні таких його способів, як аналіз структури, динаміки та відхилень (від встановлених норм) витрат тощо. А загалом, для досягнення ефективності застосування результатів аналізу операційних витрат при прийнятті управлінських рішень на підприємствах, він має виконувати такі завдання:

-підтвердження (заперечення) обґрунтованості прийнятих управлінських рішень щодо операційних витрат;

- об'єктивна та неупереджена оцінка виконання управлінських рішень та виявлення відхилень фактично понесених витрат від запланованих їх обсягів;

- з'ясування чинників відхилень;

- пошук резервів і шляхів зниження собівартості продукції та послуг; виробництві.

- розробка заходів із мобілізації внутрішньовиробничих резервів та використання їх у

Відповідно до цих завдань можуть бути використані різні методи аналізу операційних витрат. Одним з найбільш прийнятних для аналізу діяльності підприємств, не лише в сенсі простоти й доступності, а й малозатратності $€$ горизонтальний та вертикальний аналіз витрат. Він дозволяє досліджувати не лише відхилення, а й структуру витрат, що важливо з позиції застосування його 
результатів для планування та прогнозування собівартості майбутньої продукції та надання послуг. В процесі здійснення такого роду аналізу необхідно:

- провести оцінку структуру операційних витрат;

- визначити абсолютні та відносні відхилення операційних витрат у звітному році порівняно 3 попереднім (чи базовим), а щодо статей витрат - встановити відхилення порівняно зі встановленим плановим завданням;

- встановити відносний вплив кожного елемента (статті) на загальну зміну витрат (собівартості).

Проводиться такий аналіз в розрізі статей та елементів витрат. Перший дозволяє ідентифрікувати найбільш вагомі статті в собівартості продукції та послуг, а другий - уможливлює вивчення складу елементів витрат, питомої ваги кожного з них при виробництві продукції та наданні послуг, а також вклад живої та уречевленої праці в виробництво. Порівнювання ж фрактичної структури витрат за кілька періодів виявляє динаміку і напрямок зміни окремих елементів, матеріаломісткості, фондомісткості, енергоємності, трудомісткості, собівартості продукції і вплив технічного прогресу на структуру витрат.

Дослідження зарубіжної літератури свідчить, що в сучасних умовах широко застосовується стратегічні методи управління, а саме SPACE-аналіз, SWOT-аналіз, стратегічні групи, моделі BCG, модель GC/ McKinsey, модель Shell-DPM, модель ADL/LC, ABC-аналіз тощо.

Аналіз операційних витрат може служити хорошою базою для розробки стратегічних напрямів діяльності. Для таких цілей нами пропонується використання ABC-аналізу. Метод ABC (Activity Based Costing) дає змогу суттєво знизити рівень інфрормаційного акумулювання у процесі прийняття управлінських рішень [9, с. 170].

Цей метод, зазвичай, активно використовують великі компанії (близько 10\%). Однак вітчизняні підприємства в цьому плані більш консервативні та не надто охоче користуються таким підходом. Причин цього можна назвати щонайменше три: вітчизняна наука недостатньо уваги приділяє дослідженню теорії і практики такого методу аналізу витрат; його методика недостатньо адаптована до специфіки українських суб'єктів господарювання та відсутні відповідні методичні рекомендації щодо його впровадження і використання; цей метод аналізу достатньо трудомісткий i, відповідно, дорожчий у застосуванні.

Метод $\mathrm{ABC}$ - це система обліку і аналізу витрат за видами діяльності організації способом процесного (поопераційного) визначення і обліку витрат. В основі методу АВС лежить припущення, що продукцію підприємство виготовляє в результаті виконання певної сукупності бізнес-процесів, кожен 3 яких потребує певних витрат. Цей метод спрямований на виявлення найбільш продуктивних видів діяльності, доцільність здійснення яких є економічно виправданою. Застосування методу АВС-аналізу передбачає важливий і трудомісткий підготовчий етап, зумовлений його специфікою [9, с. 171-172].

Обґрунтуванням доцільності застосування методу АBC-аналізу полягає у раціональному розподілі операційних витрат в процесі господарської діяльності підприємств. Застосовуючи АВСаналіз для оцінки операційних витрат на підприємствах, необхідно зібрати наступну інформацію:

- ідентифікувати основні операції, які здійснюються підприємством;

- визначити носії (драйвери) витрат (драйвер витрат (cost driver - «кост драйвер») - показник виміру активності виду діяльності, що відображає суть такого виду діяльності і взаємопов'язаний 3 об'єктом калькулювання);

-ідентифікувати операційні витрати за кожним з видів діяльності;

- скалькувати (перенести) витрати з видів діяльності на види товарів і послуг, які реалізуються.

Цей метод аналізу також дозволяє виявляти взаємозв'язок витрат на надання послуг в розрізі споживачів (замовників) послуг. На підставі ABC-методу можна виявити управлінські пріоритети щодо стратегії розвитку підприємства й на цій основі в подальшому обирати найбільш прийнятний метод аналізу. Основним критерієм обґрунтування вибору має бути ефективність та оперативність.

Висновки 3 проведеного дослідження. Проведене дослідження показало, що в процесі діяльності підприємства стикаються з різними проблемами ситуаціями, в основі яких лежать результати неякісно проведеного аналізу операційних витрат. Зокрема, неправильно інтерпретовані дані часто призводять до банкрутства в разі прийняття неправильних управлінських рішень. У результаті проведеного дослідження одержано висновки й зроблено обґрунтування доцільності використання для цілей проведення аналізу операційних витрат джерел внутрішньої та зовнішньої інформації. Запропоновано розширювати інформаційні джерела відповідно до існуючих можливостей, а також з урахуванням потреб, для яких проводиться аналіз. В такому разі буде враховано об'єктивні, а також релевантні дані і аналіз даватиме більш якісні й адекватні результати.

Щодо методів аналізу, то критична оцінка чинної української практики вказує на недостаню увагу до використання сучасних інноваційних його підходів та інструментарію. Корисним в цьому контексті буде використання позитивного зарубіжного досвіду. Але при цьому $є$ потреба у формуванні рекомендацій щодо удосконалення методів аналізу операційних витрат та визначення альтернативних шляхів їх оптимізації для уникнення можливих ризиків у стратегічній перспективі підприємств, що $є$ актуальним і перспективним напрямом розвитку подальших наукових досліджень. 


\section{Література}

1. Абрамова О. В. Аналіз витрат операційної діяльності підприємства : автореф. дис. ... канд. екон. наук: 08.00.09. Київ : ДВНЗ «Київський національний економічний університет імені Вадима Гетьмана», 2015. 20 с.

2. Адирова Т.І. Проблеми управління витратами на матеріальне забезпечення та шляхи їх подолання на виробничому підприємстві. Економіка та держава. 2012. № 12. С. 71-73.

3. Андрющенко Н. С. Формування інформації про адміністративні витрати в управлінському обліку. Облік і фрінанси АПК. 2010. № 1. С. 42-46.

4. Безверхий К. Сучасні підходи до вдосконалення обліку непрямих витрат на збут, рекламу і маркетинг. Бухгалтерський облік і аудит. 2010. № 12. С. 14-19.

5. Бланк И. А. Управление прибылью. Киев : Ника-Центр, 2000. 544 с.

6. Венжега Д.І. Поняття обліку витрат на виробництво та шляхи його вдосконалення. Інноваційна економіка. 2012. № 11. С. 294-297.

7. Друри К. Учет затрат методом стандарт-кост / пер. с англ. под ред. Н. Д. Эриашвили. Москва : Аудит, ЮНИТИ, 1998. 224 с.

8. Дьордяй В.П., Макарович В.К. Аналіз операційних витрат на підприємствах енергорозподільчої галузі. Бухгалтерський облік, аналіз, аудит та оподаткування : тези Всеукраїнської науково-практичної on-line конференції здобувачів вищої освіти і молодих учених, присвяченої Дню науки (м. Житомир, 15-17 травня 2019 року). Житомир : ЖДТУ, 2019. С. 302.

9. Івахів Ю., Спільник І. Метод АВС-аналізу: доцільність застосування. Економічний аналіз. 2008. Випуск 3(19). С. 170-172.

10. Котляров С. А. Управление затратами. Санкт-Петербург : Питер, 2001. 160 с

11. Нападовська Л. В. Управлінський облік : монографія. Дніпропетровськ : Наука і освіта, 2000. $450 \mathrm{c}$.

12. Рокожиця А. Ю., Івата В. В. Аналіз операційних витрат. Бухгалтерський облік, аналіз та aудuт. 2017. Випуск 6(11). С. 370-374.

13. Струк Н., Корицька О. Оцінка й оцінювання діяльності промислових підприємств України: фрінансово-статистичний підхід. Економічний аналіз. 2012. Випуск 11. Ч. 3. С. 66-70.

14. Фандель Г. Теорія виробництва і витрат / Пер. з нім. під кер. М. Г. Герещак. Київ : Таксон, 2000. 520 c.

15. Фокін О. К. Оцінка стану витрат великих промислових підприємств як об'єкта управління та економічного аналізу. Вісник ЖДТУ. 2019. № 1(87). С. 117-127.

16. Череп А.В. Управління витратами суб'єктів господарювання : монографія. Харків : ВД “Інжек”, 2006. Ч.1. 368 с.

17. Чичуліна К.В., Чапча І. О. Формування оптимальної системи управління витратами підприємства (на прикладі ПРАТ «Полтавський машинобудівний завод»). Ефективна економіка. 2019. № 1. DOI: 10.32702/2307-2105-2019.1.39.

\section{References}

1. Abramova, O.V. (2015), "Cost analysis of operation activity of enterprise", Thesis abstract for Cand. Sc. (Econ.), 08.00.09, DVNZ "Kyivskyi natsionalnyi ekonomichnyi universytet imeni Vadyma Hetmana”, Kyiv, Ukraine, $20 \mathrm{p}$.

2. Adyrova, T.I. (2012), "Problems of managing the costs of material support and ways to overcome them at the manufacturing enterprise", Ekonomika ta derzhava, no. 12, pp. 71-73.

3. Andriushchenko, N.S. (2010), "Formation of the information on administrative costs in management accounting", Oblik i finansy APK, no. 1, pp. 42-46.

4. Bezverkhyi, K. (2010), "Modern approaches to improving the accounting for indirect costs of sales, advertising and marketing", Bukhhalterskyi oblik $i$ audit, no. 12, pp. 14-19.

5. Blank, I.A. (2000), Upravleniye pribylyu [Profit management], Nika-Tsentr, Kyiv, Ukraine, 544 p.

6. Venzheha, D.I. (2012), "Accounting concepts costs and ways to improve", Innovatsiina ekonomika, no. 11 , pp. 294-297.

7. Drury, C. (1998), Uchet zatrat metodom standart-kost [Standard Costing], trans. from English edited by N. D. Eriashvili, Audit, YUNITI, Moscow, Russia, 224 p.

8. Dordiai, V.P. and Makarovych, V.K. (2019), "Analysis of operating expenses at the enterprises of the energy distribution industry", Bukhhalterskyi oblik, analiz, audyt ta opodatkuvannia: tezy Vseukrainskoi naukovo-praktychnoi on-line konferentsii zdobuvachiv vyshchoi osvity i molodykh uchenykh, prysviachenoi Dniu nauky [Accounting, analysis, audit and taxation : theses of the All-Ukrainian scientific and practical Online conference of higher education applicants and young scientists on the Day of science], (Zhytomyr, May 15-17, 2019), ZhDTU, Zhytomyr, Ukraine, p. 302.

9. Ivakhiv, Yu. and Spilnyk, I. (2008), "Method of ABC-analysis: appropriateness of use", Ekonomichnyi analiz, iss. 3(19), pp. 170-172. 
10. Kotlyarov, S.A. (2001), Upravleniye zatratami [Cost management], Piter, Sankt-Peterburg, Russia, $160 \mathrm{p}$.

11.Napadovska, L.V. (2000), Upravlinskyi oblik [Management accounting], monograph, Nauka i osvita, Dnipropetrovsk, Ukraine, $450 \mathrm{p}$.

12.Rokozhytsia, A.Yu. and Ivata, V.V. (2017), "Analysis of operating expenses", Bukhhalterskyi oblik, analiz ta audyt, iss. 6(11), pp. 370-374.

13.Struk, N. and Korytska, O. (2012), "Assessment and evaluation of industrial enterprises activity of Ukraine: financial and statistical approach", Ekonomichnyi analiz, iss. 11, part 3, pp. 66-70.

14.Fandel, H. (2000), Teoriia vyrobnytstva $i$ vytrat [The theory of production and costs], Trans. from German edited by M.H. Hereshchak, Takson, Kyiv, Ukraine, 520 p.

15.Fokin, O.K. (2019), "Estimation of the costs of large industrial enterprises as the object of management and economic analysis", Visnyk ZhDTU, no. 1(87), pp. 117-127.

16.Cherep, A.V. (2006), Upravlinnia vytratamy subiektiv hospodariuvannia [Cost management of business entities], monograph, VD "Inzhek", part 1, Kharkiv, Ukraine, 368 p.

17.Chychulina, K.V. and Chapcha, I.O. (2019), "Formation of the optimal enterprise cost management system (for example PJSC "Poltava machine-building plant")", Efektyvna ekonomika, no. 1, DOI: 10.32702/2307-2105-2019.1.39.

Стаття надійшла до редакції 21.10.2019 р.

УДК 336.672

JEL Classification: G33, M49

DOI: 10.37332/2309-1533.2019.7-8.20

Горлачук О.A.,

канд. екон. наук, судовий експерт сектору економічних досліджень відділу товарознавчих, гемологічних, економічних, будівельних, земельних досліджень та оціночної діяльності, Тернопільський науково-дослідний експертно-криміналістичний центр МВС України

\title{
ПРОВЕДЕННЯ СУДОВИХ ЕКОНОМІЧНИХ ЕКСПЕРТИЗ, ПОВ'ЯЗАНИХ ІЗ ДОВЕДЕННЯМ СУБ'ЄКТІВ ГОСПОДАРЮВАННЯ ДО БАНКРУТСТВА
}

\author{
Horlachuk O.A., \\ cand.sc.(econ.), judicial expert of the economic research \\ sector of the department of commodity, hemological, \\ economic, construction, land research and evaluation \\ of Ternopil Research Experimental Judicial \\ Center of Internal Affairs of Ukraine
}

\section{CONDUCTING JUDICIAL ECONOMIC EXPERTISE RELATED TO BRINGING BANKRUPTCY ENTITIES}

Постановка проблеми. Загальновідомо, що в умовах ринкового середовища підприємницька діяльність здійснюється з певним елементом ризику і характеризується невизначеністю кінцевих результатів. При цьому ринкова економіка не має детермінантів в розмірах отримуваного прибутку на авансований капітал, із зростанням якого підвищується і ймовірний фінансовий ризик, що за певних обставин може призвести до реального банкрутства підприємства внаслідок настання його неплатоспроможності.

Такий фінансовий стан може бути зумовлений як об'єктивними ендогенними та екзогенними фракторами (зміна кон'юнктури, політична ситуація, неефективний менеджмент), так і цілеспрямованими, навмисними діями самого суб'єкта господарювання, які за правовим визначенням 